\title{
Extended process failure mode and effect analysis (PFMEA) for the automotive industry: The FSQC-PFMEA
}

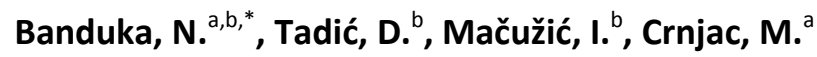 \\ ${ }^{a}$ University of Split, Faculty of Electrical Engineering, Mechanical Engineering and Naval Architecture, Split, Croatia \\ bUniversity of Kragujevac, Faculty of Engineering, Kragujevac, Serbia
}

\section{A B S T R A C T}

This paper mainly addresses constraints of the PFMEA for the automotive industry. The safety and cost aspect are integrated into traditional severity index. Therefore, for this purpose, three new indices are invented - safety severity index; quality severity index and cost severity index. For both safety severity index and cost severity index, new tables with crisp values belong to the interval (1-10) were invented. While for quality severity index was kept traditional severity table for the automotive industry. The relative importance of these three indices is stated by the fuzzy pair-wise comparison matrix. The weights vectors are calculated by applying the extent analyses. In order to overcome these constraints, but to keep traditional framework of the PFMEA for automotive industry, new fuzzy PFMEA with respect to safety, quality and cost (FSQC-PFMEA) is presented. It can be denotes as the main findings of this paper. At last, the proposed model is tested by real-life data which come from one automotive company supplier and compared with traditional way in the case study. Chosen company use IATF 16949 standard for automotive industry and reference manual presented by Automotive Industry Agency Group (AIAG). Therefore, use of the PFMEA is obligated in this company.
\end{abstract}

\section{ARTICLE INFO}

Keywords:

Automotive industry;

Process failure mode and effect

analysis (PFMEA);

FSQC-PFMEA;

Fuzzy AHP

*Corresponding author: nikola.banduka90@gmail.com (Banduka, N.)

Article history:

Received 25 February 2018

Revised 30 May 2018

Accepted 4 June 2018

\section{References}

[1] Stamatis, D.H. (2003). Failure mode and effect analysis: FMEA from theory to execution, ASQ Quality Press, Milwaukee, Wisconsin, USA.

[2] Banduka, N., Mačužić, I., Stojkić, Ž., Bošnjak, I., Peronja, I. (2016). Using 80/20 principle to improve decision making at PFMEA, In: Proceedings of the 27th DAAAM International Symposium, Vienna, Austria, 487-492, doi: 10.2507/27th.daaam.proceedings.073.

[3] Automotive industry action group (AIAG). Potential failure mode \& effect analysis, from https://www.aiag.org/ store/publications/details?ProductCode=FMEA-4, accessed May 29, 2018.

[4] Liu, H.-C., Liu, L., Liu, N. (2013). Risk evaluation approaches in failure mode and effects analysis: A literature review, Expert systems with applications, Vol. 40, No. 2, 828-838, doi: 10.1016/j.eswa.2012.08.010.

[5] IATF 16949:2016 (2016). Quality management system requirements for automotive production and relevant service parts organizations, SMMT - Society of Motor Manufacturers and Traders, 1st edition.

[6] ISO/TS 16949:2009. (2009). Quality management systems - Particular requirements for the application of ISO 9001:2008 for automotive production and relevant service part organizations (second revision), Bureau of Indian Standards, New Delhi.

[7] Johnson, K.G., Khan, M.K. (2003). A study into the use of the process failure mode and effects analysis (PFMEA) in the automotive industry in the UK, Journal of Materials Processing Technology, Vol. 139, No. 1-3, 348-356, doi: 10.1016/S0924-0136(03)00542-9.

[8] Zammori, F., Gabbrielli, R. (2012). ANP/RPN: A multi criteria evaluation of the risk priority number, Quality and Reliability Engineering International, Vol. 28, No. 1, 85-104, doi: 10.1002/qre.1217. 
[9] Braglia, M. (2000). MAFMA: Multi-attribute failure mode analysis, International Journal of Quality \& Reliability Management, Vol. 17, No. 9, 1017-1033, doi: 10.1108/02656710010353885.

[10] Banduka, N., Veža, I., Bilić, B. (2016). An integrated lean approach to process failure mode and effect analysis (PFMEA): A case study from automotive industry, Advances in Production Engineering \& Management, Vol. 11, No. 4, 355-365, doi: 10.14743/apem2016.4.233.

[11] Baynal, K., Sarı, T., Akpınar, B. (2018). Risk management in automotive manufacturing process based on FMEA and grey relational analysis: A case study, Advances in Production Engineering \& Management, Vol. 13, No. 1, 6980, doi: $10.14743 /$ apem2018.1.274.

[12] Liu, H.-C., You, J.-X., Ding, X.-F., Su, Q. (2015). Improving risk evaluation in FMEA with a hybrid multiple criteria decision making method, International Journal of Quality \& Reliability Management, Vol. 32, No. 7, 763-782, doi: 10.1108/IJQRM-10-2013-0169.

[13] Zimmermann, H.-J. (1996). Fuzzy set theory - And its applications, Springer, Dordrecht, The Netherland.

[14] DuBois, D., Prade, H. (1980). Fuzzy sets and systems: Theory and applications, Academic press, London, UK.

[15] Kaya, T., Kahraman, C. (2011). Multicriteria decision making in energy planning using a modified fuzzy TOPSIS methodology, Expert Systems with Applications, Vol. 38, No. 6, 6577-6585, doi: 10.1016/i.eswa.2010.11.081.

[16] Tadic, D., Aleksic, A., Mimovic, P., Puskaric, H., Misita, M. (2016). A model for evaluation of customer satisfaction with banking service quality in an uncertain environment, Total Quality Management \& Business Excellence, 1-20, doi: $10.1080 / 14783363.2016 .1257905$.

[17] Saaty, T.L. (1990). How to make a decision: The analytic hierarchy process, European Journal of Operational Research, Vol. 48, No. 1, 9-26, doi: 10.1016/0377-2217(90)90057-I.

[18] Kwong, C.K., Bai, H. (2003). Determining the importance weights for the customer requirements in QFD using a fuzzy AHP with an extent analysis approach, IIE Transactions, Vol. 35, No. 7, 619-626, doi: 10.1080/074081703 $\underline{04355}$.

[19] Aleksić, A., Stefanović, M., Tadić, D., Arsovski, S. (2014). A fuzzy model for assessment of organization vulnerability, Measurement, Vol. 51, 214-223, doi: 10.1016/j.measurement.2014.02.003.

[20] Tadić, D., Stefanović, M., Aleksić, A. (2014). The evaluation and ranking of medical device suppliers by using fuzzy topsis methodology, Journal of Intelligent \& Fuzzy Systems, Vol. 27, No. 4, 2091-2101, doi: 10.3233/IFS141174.

[21] Macdonald, D. (2004). Practical machinery safety, 1st edition, Newnes, The Netherlands.

[22] Banduka, N., Veža, I., Bilić, B., Mačužić, I., Radojičić, M. (2017). Using cost-based mathematical model and principle 80/20 to improve decision making for risk priority at FMEA, In: XVII International Scientific Conference on Industrial Systems (IS'17), Novi Sad, Serbia, 318-323.

[23] Chang, D.-Y. (1996). Applications of the extent analysis method on fuzzy AHP, European Journal of Operational Research, Vol. 95, No. 3, 649-655, doi: 10.1016/0377-2217(95)00300-2.

[24] Apak, S., Tozan, H., Vayvay, O. (2016). A new systematic approach for warehouse management system evaluation, Tehnički vjesnik - Technical Gazette, Vol. 23, No. 5, 1439-1446, doi: 10.17559/TV-20141029094700.

[25] Durán, O. (2015). Spare parts criticality analysis using a fuzzy AHP approach, Tehnički vjesnik - Technical Gazette, Vol. 22, No. 4, 899-905, doi: 10.17559/TV-20140507002318.

[26] Yager, R.R. (1993). On ordered weighted averaging aggregation operators in multi-criteria decisionmaking, In: Readings in Fuzzy Sets for Intelligent Systems, Morgan Kaufmann, USA, 80-87, doi: 10.1016/B978-1-4832-14504.50011-0. 